\title{
ОСОБЛИВОСТІ ПСИХОЛОГІЧНОЇ РОБОТИ З ЕМОЦІЙНИМИ СТАНАМИ БАТЬКІВ ДІТЕЙ 3 ПСИХОФІЗИЧНИМИ ПОРУШЕННЯМИ РАННЬОГО ВІКУ
}

УДК:159.9. 616.092

\section{Шульженко Діна Іванівна}

\begin{abstract}
Доктор психологічних наук, професор кафедри психокорекиійної педагогіки Факультету корекційної педагогіки та психологї Національного педагогічного університету імені М. П. Драгоманова, м. Київ (Украӥна)
\end{abstract}

\begin{abstract}
Анотація. На сьогодні в Україні, у сфері психологічної допомоги неповносправним людям спостерігається відсутність чіткої та сформованої психологічної допомоги батькам дітей з особливими освітніми потребами. Аргументовано та узагальнено важливість роботи над психоемоційною сферою батьків. Психологічна допомога для батьків складається з етапів, які йдуть почергово. Етапи роботи: інформативний, діагностичний, психологоконсультативний. Проаналізовано теорію і методику соиіально-психологічної роботи з родиною, яка виховує дитину з психофізичними порушеннями. Узагальнено та удосконалено практичну концепцію на основі опрацььованих теоретичних засад та психологічних досліджень роботи 3 батьками дітей з особливими освітніми потребами. Представлено комплекс роботи з родинами, щуо спрямований на корекцією та стабілізацію емоційних станів у батьків, роботою над взаєминами у сім'ї. Обтрунтовано важливість роботи саме з емоиійною сферою батьків та надання психолого-консультативних послуг иілій сім'ї. На основі різних принципів, а саме: психокорекції, виховних, сімейно-центрованих та мотиваційних представлено різноманітні моделі психологічної допомоги родинам осіб з особливими освітніми потребами, які описані в даній статmi.
\end{abstract}

Ключові слова: проблеми батьків дітей з порушеннями розвитку; емоиійні стани, депресія, гнів, прийняття, тривога, почуття провини; моделі психологічної допомоги родинам.

Постановка проблеми. Системна до- цепція психологічних послуг для батьків дітей помога дітям із психофізичними порушеннями грунтується на чіткому розумінні особли3 особливими освітніми потребами, робить востей психологічної допомоги батькам діперші кроки в Україні. На основі різних принтей $з$ особливими освітніми потребами. Конципів формувалися різноманітні моделі психологічної допомоги родинам осіб з особливими 
освітніми потребами.

Формулювання мети статті. Теорія й методика соціально-психологічної роботи 3 сім'єю, яка виховує дитину з обмеженими можливостями розвитку досліджувалась багатьма авторами, проте не існує єдиної, чіткої наукової структури роботи з батьками дітей 3 особливими освітніми потребами. Саме тому метою даної статті є узагальнення та удосконалення практичної концепції на основі опрацьованих теоретичних засад та психологічних досліджень роботи з емоційною сферою батьків дітей з особливими освітніми потребами.

Аналіз досліджень і публікацій. Досліджено вплив народження дитини з порушеннями на психоемоційний стан та адаптацію батьків (Н. Бастун, Р. Кравченко, А. Кравцова, К. Островська, М. Радченко, М. Сварник, Л. Шипіцина, М. Batshaw, Н. Borzyszkowska, M. Koscielska, D. Lobato). На основі різних принципів, а саме: принципів спеціальної дидактики виховних, сімейно центрованих та мотиваційних формувалися різноманітні моделі психологічної допомоги родинам осіб 3 особливими освітніми потребами. Модель Б. Ф. Скінера спиралися на принципи збільшення кількості та якості взаємодійінтеракцій дитини і батьків. Модель В. Є. Кагана, спирається на принцип стимулювання батьків до виникнення у них забутих інтересів і захоплень. На думку автора, для них як осіб, для їх роботи з дитиною необхідне повернення до улюбленої роботи і до особистісного розвитку. Сутність моделі полягає в дотриманні терапевтичної дистанції без відмови від просто людського контакту з батьками. Модель Х. Джайнотта - спілкування батьків 3 дітьми спирається на те, щоу всіх ситуаціях батьки підтримують позитивний образ «Я» у дитини; уникають особистісних негативних оціночних суджень. Модель В. В Тарасун спирається на принцип вирішення проблеми раннього прогнозування і своєчасного запобігання труднощів у навчанні дітей з особливими освітніми потребами. Важливого значення при побудові стратегії надання психологічної допомоги родинам, які виховують дитину 3 особливими освітніми потребами, мають базові положення теорій: психолого-педагогічних закономірностей розвитку дитини з психофізичними порушеннями, як результату складного процесу його соціалізації (Т. А. Власова, Л. С. Виготський, В. І. Лубовський, Д. Б. Ельконін) та розвитку в умовах дизонтогенезу, який потребує створення спеціального корекційно-розвивального середовища (К. С. Лебединська, В. В. Лебединський, І. Ю. Левченко, В. І. Лубовський, С. М. Мастюкова, М. С. Певзнер, В.Г. Петрова, С. Я. Рубінштейн, В. М. Синьов, У. В. Ульєнкова). Під спеціальним корекційно-розвивальним середовищем в родині мається на увазі внутрішньо-сімейні умови, які створюються батьками і забезпечують оптимальний розвиток дитини з різними нозологічними порушеннями.

Теорія й методика соціально- 
психологічної роботи з сім'єю, яка виховує дитину з обмеженими можливостями розвиткудосліджувалась багатьма авторами: І. Іванова, I. Коробейников, А. Маллєр, І. Мамайчук, В. Мартинов, О. Мастюкова, Г. Мішина, К. Островська, Н. Фінні, Л. Ханзерук, Д. Шульженко та ін).

Виклад основного матеріалу. Різні ситуації виникають через реакції батьків на хворобу, ваду чи інвалідність дитини. М. Семаго і Р. Майромян виділяють чотири фази реакції батьків на народження дитини з вадами розвитку. Перша - стресовий стан, коли подружжя відчувають страх, відчай і розгубленість. Вони ставлять собі запитання: «чому це повинно було статися зі мною»?. Згодом виникає почуття провини, хоча лікар запевняє, що хвороба була неминучою. Друга - фаза динаміки психологічного стану сім'ї - негативізм, заперечення діагнозу. У такому випадку заперечення батьками патологічного стану дитини розглядається як засіб (що не усвідомлюється ними) для подолання пригніченості і тривоги. Деякі батьки висловлюють недовіру лікарям і консультантам, багаторазово уточнюють діагноз. Характерною рисою цієї фази $\epsilon$ проекція власного почуття провини на iнших, яка носить внутрішньо сімейний і поза сімейний характер. Батьки можуть звинувачувати один одного, лікарів. Характер проекції може відволікати енергію від адекватного вирішення проблеми, призводить до напружених відносин і підвищує емоційну напруже- ність. У такому випадку батьки зосереджені саме на хворобі, ваді дитини і не помічають позитивних ознак іiі особистості чи збережених можливостей і якостей, яких не зачепила хвороба. Третя фаза - депресивний стан, пов'язаний з усвідомленням справжнього становища, втратою сподівань на те, що їхня дитина може бути нормальною. Сум, горе часто можуть не проявлятись безпосередньо, але переживання тих почуттів позначається на стосунках сім'ї. Зменшується інтерес до роботи та інших справ, спостерігається роздратування, гнів, бракує теплоти у стосунках. Безперервна потреба дитини у спеціальному догляді може ускладнити вирішення цієї проблеми, підсилити синдром «хронічної печалі», що $є$ наслідком постійної залежності дитини від батьків, асоціалізації іï психічного чи фізичного дефекту. Це може призвести до емоційної ізольованості, відчуженості подружжі. Деякі пари залишаються разом із спільного почуття провини і обов'язку, але їх задоволення шлюбом може послабшати, може настати сексуальна дисгармонія. Четверта фаза - означає початок соціально-психологічної адаптації членів сім’ї, адекватних емоиійних контактів. На думку М. Семаго і Р. Майромяна, ці етапи носять скоріш структурний ніж послідовнопочасовий характер, і залежно від мікросередовища, особливостей внутрішньо сімейної ситуації можуть мати різну тривалість і виявлення $[3,2]$.

Емоційне відкидання найчастіше має 
місце, коли дитина не виправдовує очікувань батьків, не задовольняє їх соціальних амбіцій, що проявляється у підвищеному рівні тривожності у дитини, іï педагогічній занедбаності та девіантній поведінці у більш старшому віці. Недостатня чуйність батьків виражається у несвоєчасному і недостатньому відгуку на потреби дітей, нехтуванні їхніми почуттями. Вони можуть виявляти надмірно сильні реакції на відхилення в поведінці дитини і не помічати іiї позитивних рис. Нечуйність батьків, особливо матерів, створює ситуацію депривації $\mathrm{i}$ ще більш сповільнює розвиток дитини, сприяє порушенню їі поведінки. Прихильність до матері - необхідна стадія психічного розвитку. Користуючись підтримкою матері, дитина набуває впевненості в собі, стає активним у пізнанні навколишнього світу. Для дитини, яка відстає в психічному розвитку, актуальність такої підтримки очевидна [1, с. 76].

Психологічноа допомоги для батьків у складається з таких етапів роботи:

- Інформаційний. Етап спрямований на надання інформації про особливості корекційного виховання дитини з особливими освітніми потребами;

- Діагностичний. Діагностування сімейної пари, з використанням психологічних методик на визначення емоційних станів.

- Психокорекційно-консультативний. Сутність етапу полягає у наданні психологічної допомоги батькам за допомогою технік сімейного консультування, які покращують їхній емоційний стан, сприяють адаптації до народження дитини 3 особливими освітніми потребами та ії̈ прийняттю, покращують характер взаємин і загалом стосунки в сім’ї. Етапи роботи спрямовані на надання інформації про виховання дитини. Практикум із корекції емоційних станів (за Е. Ільїн) передбачає використання таких музично-медитативні вправ, як: очищення від страждань, позбавлення почуття провини, позбавлення від злобного роздратування - самоконтроль, розслаблення - великий спокій, формування оптимізму - радість життя, радість любові [5].

Отже, враховуючи психологічний стан і особливу вразливість родини дитини 3 психофізичними порушеннями, потрібно надавати родині практичну допомогу та інформаційну підтримку. Зниження стресу й поліпшення внутрішньо-сімейних стосунків справлятимуть позитивний вплив на розвиток дитини. В основу роботи корекційного психо-педагога 3 сім'єю, де є дитина з психофізичними порушеннями, окрім принципу комплексного підходу до організації корекційно-педагогічного процесу, мають бути покладені й такі принципи:

єдності діагностики i корекційнопедагогічного процесу. Обстеження дитини різними фахівцями проводиться задля визначення іiї актуального та потенційного рівнів розвитку, соматичного стану і тощо, а також для визначення шляхів корекційнопедагогічної роботи у вигляді, скажімо, скла- 
дання індивідуальної програми розвитку; тісної співпраці між батьками і фахівцями, батьками та дітьми. Ще раз наголосимо, що батьки шукатимуть підтримки та допомоги фахівця, прислухатимуться до нього і виконуватимуть його поради лише тоді, коли професіонал сприйматиме батьків не як «об'єкта свого впливу», а як рівноправного партнера по корекційному процесу. Так само стосунки між корекційним педагогом і дитиною та батьками і дитиною мають будуватися за відомим принципом особистісно-орієнтованої педагогіки, а саме, «на рівні очей» дитини, використовуючи прийом «очі в очі»;

урахування інтересів (принцип вирішення того чи іншого завдання через інтерес), за якого фахівцеві потрібно вельми тактовно й аргументовано підходити до відповідей на питання, що цікавлять батьків дитини;

провідної діяльності розвиток дитини має відбуватись у межах її основної діяльності, отже і співпраця корекційного педагога та родини повинна спрямовуватися на формування діяльності дитини відповідно до ії віку, можливостей, інтересів.

У корекційній роботі з батьками фахівці, до того ж, повинні використовувати сучасні форми та методи роботи, враховуючи індивідуальні особливості батьків, типи сімей, міжособистісні стосунки та стилі виховання. Робота фахівців і батьків 3 дитиною має бути регулярною й довготривалою, а відтак фахівці на різних лекціях, семінарах, заняттях, тренін- гах і практикумах повинні надавати теоретичні знання батькам і навчати їх відпрацьовувати техніки і прийоми роботи 3 дитиною.

Окрім того, слід сказати, що враховуючи наш досвід і досвід зарубіжжя, що служба ранньої корекційної допомоги сім'ям, які мають таких дітей може стати однією 3 нових ланок системи спеціальної освіти в Україні.

Висновки. Емоційні стани, батьківське ставлення, соціально-сімейні стосунки та хронічну втому можна змінити у результаті психокорекційної допомоги, що була поділена на блоки з урахуванням індивідуальності кожної сім'ї: групової роботи, індивідуального та сімейного консультування для батьків дітей 3 особливими потребами. На корекційновиховний результат впливають чинники: знання батьками психології дитини, вірна оцінка її індивідуальних якостей, адекватний емоційний відгук на поведінкові реакції дитини, вибір підходящого способу взаємодії з дитиною, який найкраще відповідає іï індивідуальним особливостям. Виховна ефективність, на нашу думку, може відбуватися лише за умов емоційної стабільності батьків, після їхнього примирення 3 хворобою дитини і відкритті в собі особистих ресурсів, на що має бути спрямована професійна психологічна допомога батькам.

Психологічний супровід такої родини, має бути спрямований на створення соціально -психологічних умов для емоційного благополуччя. Після терапії батьки дітей з особливи- 
ми потребами розуміють, про необхідність організації процесу виховання і лікування дитини, саме поетапно і маленькими кроками. У них змінюється світобачення і міняється мислення у позитивну сторону, внаслідок отриманої інформації про виховання та особливості їхньої дитини. Важливий аспект психологічної роботи це - розуміння самостійності у вирішенні своїх проблем, а головне мотивації до вирішення, до успіху і щасливого життя у вигляді проходження усіх стадій адаптації народження дитини 3 неповносправністю. Розробка моделі психологічної допомоги для батьків охоплює всі аспекти, починаючи від психологічної діагностики психоемоційних станів та підбору методів для їх покращення та корекції переживань. Ефективність впливу має на меті також і забезпечення нормального функціонування дитини 3 психофізичними розладами у сім’ї та суспільстві. Компоненти психологічних послуг, а також етапність їх виконання, результатом реалізації якої $є$ покращення та оптимальні емоційні стани, переживання та сприятливий клімат у сім'ї батьків дітей з особливими потребами, соціалізація батьків та дитини. В результаті ми отримали низку результатів, які мають важливе наукове та прикладне значення і будуть стимулювати як постановку нових експериментальних досліджень, так і розробку наукових основ психологічного та психотерапевтичного супроводу батьків дітей з особливими потребами раннього віку.

\section{Перелік використаних джерел:}

1. Глуханюк T. Допомога психолога сім'ї, де росте дитина 3 порушенням інтелекту T. Глуханю. [Електронний ресурс]. Режим доступу :http://www.ippo.if.ua /predmety /ocppsr /index.php? $\mathrm{r}=$ site/ stattya\&id=76.].

2. Душка А. Л. Роль сім’ї у соціалізації неповносправної дитини. / А.Л. Душка // Наука і освіта. - Одеса, 2009. № 1-2. - С. 48-52.

3. Ейдемиллер Е. Психология и психотерапия семи / Е. Ейдемиллер, В. Юстицкис. - 3-е изд. - СПб.: Питер, 2002. $-656 \mathrm{c}$.

4. Железняк Л. С. Опыт включения детей с проблемами развития в состав психотерапевтических групп / Л. С. Железняк, И. Б. Карвасарская // Обозрение психиатрии и мед. психологии. - 1993. - № 1. - С. 102-104.

5. Ильин Е. П. Эмоции и чувства. - СПб: Питер, 2001. $752 \mathrm{c}$.

6. Островська К. О. Психологічні особливості ставлення матерів до їх здорових дітей та дітей з обмеженими можливостями / К.О. Островська // Науковий часопис НПУ ім. М. П. Драгоманова : збірник наукових праць ; за ред. В. М. Синьова.- К. : НПУ ім. М. П. Драгоманова, 2015. - Вип. 29. - Сер. № 19. Корекційна педагогіка та спеціальна психологія. - С. 213-219.

7. Trzebinska E. Psychologia pozytywna, Warszawa 2008

8. Twardowski A. Sytuacja rodzin dzieci niepełnosprawnych / A. Twardowski; [red. I. Obuchowska] // Dziecko niepełnosprawne w rodzinie. - Warszawa : WSiP., 1991. - S.18 - 54.

9. Blasher J., Sequential stages of parental adjustment to the birth of a child with handicaps : fact or artifact? Mental retardation. 1984. Vol. 22. P. 55-68.

\section{References (Transliteration):}

1. Glukhanyuk T. Dopomoga psikhologa sim'ï. De roste ditina $\mathrm{z}$ porushennyam intelektu/ 
T. Glukhanyu. [Elektronniy resurs]. Rezhim dostupu :http:// www.ippo.if.ua/ predmety/ ocppsr/ index.php?r =site/ stattya\&id=76.].

2. Dushka A. L. Rol sim’ï u sotsializatsii nepovnospravnoï ditini. / A.L. Dushka // Nauka i osvita. - Odesa. 2009. - № 1-2. - S. 48-52.

3. Eydemiller E. Psikhologiya i psikhoterapiya semi / E. Eydemiller. V. Yustitskis. - 3-e izd. - SPb.: Piter. 2002. $656 \mathrm{~s}$.

4. Zheleznyak L. S. Opyt vklyucheniya detey s problemami razvitiya $\mathrm{v}$ sostav psikhoterapevticheskikh grupp / L. S. Zheleznyak. I. B. Karvasarskaya // Obozreniye psikhiatrii i med. psikhologii. - 1993. - № 1. - S. 102-104.

5. Ilin E. P. Emotsii i chuvstva. - SPb: Piter. 2001. - 752 s.

6. Ostrovska K. O. Psikhologichni osoblivosti stavlennya materiv do ikh zdorovikh ditey ta ditey $\mathrm{z}$ obmezhenimi mozhlivostyami / K.O. Ostrovska // Naukoviy chasopis NPU im. M. P. Dragomanova : zbirnik naukovikh prats ; za red. V. M. Sinova.- K. : NPU im. M. P. Dragomanova. 2015. - Vip. 29. - Ser. № 19. Korektsiyna pedagogika ta spetsialna psikhologiya. - S. 213-219.

7. Trzebinska E. Psychologia pozytywna. Warszawa 2008

8. Twardowski A. Sytuacja rodzin dzieci niepe? nosprawnych / A. Twardowski; [red. I. Obuchowska] // Dziecko niepe?nosprawne w rodzinie. - Warszawa : WSiP.. 1991. - S.18-54.

9. Blasher J. Sequential stages of parental adjustment to the birth of a child with handicaps : fact or artifact? Mental retardation. 1984. Vol. 22. P. 55-68.

\section{Shulzhenko Dina}

Doctor of Psychological Sciences, Professor of the Department of Psycho-Corrective Pedagogy of The Faculty of Correctional Pedagogics and Psychology of M. P. Drahomanov National Pedagogical University, Kiev (Ukraine)

FEATURES OF PSYCHOLOGICAL WORK WITH EMOTIONAL STATES OF PARENTS OF YOUNG CHILDREN WITH PSYCHOPHYSICAL DISORDERS

\section{ABSTRACT}

The most common in correctional education is a child anomalies classification by type of violation. Such knowledge defined the content and methods of work with the child and form of education and training. The scholarly objective is to study: problems related to the illness of the child which determine the emotional state of parents having a child with special needs; the stages of experience of the birth of a sick child, and types of emotional reactions of parents. Traditionally the problem of families who raise children with special needs are considered exclusively through the prism of the child's problems. In most cases, assistance is limited to consulting on the issues of upbringing and education, however little attention is given to a very serious aspect, i.e. the emotional state of the parents themselves. To help them, it is important to understand what happens to a person when his/her child is diagnosed with a disease and how it affects the life on the whole. The article analyzes the scholarly data and approaches to the study of: problems of parents arising from their child's illness; emotional states in parents raising a child with developmental impairments; and stages of experience of having a sick child. One of the main prerequisites for the adequate development of a child is upbringing in an emotionally favorable and stable social environment. The family is one of these environments; this is where the foundation are laid for future skills required for successful human existence in the outside world. The practical objective of our 
research is the basis for designing psychological support for parents raising a child with developmental disabilities.

Key words: emotional states of parents of children with developmental disabilities, denial, depression, anger, acceptance, guilt, a stage of emotional experience of the birth of a sick child, psychological aid.

\section{Шульженко Дина Ивановна}

Доктор психологических наук, профессор кафедры психокоррекционной педагогики Факультета коррекционной педагогики и психологии Национального педагогического университета имени М. П. Драгоманова, г. Киев (Украина)

\section{ОСОБЕННОСТИ ПСИХОЛОГИЧЕСКОЙ РАБОТЫ С ЭМОЦИОНАЛЬНЫМИ СОСТОЯНИЯМИ РОДИТЕЛЕЙ ДЕТЕЙ PАННЕГО ВОЗРАСТА С ПСИХОФИЗИЧЕСКИМИ НАРУШЕНИЯМИ}

Аннотация. В статье научно обоснованная терминология: психофизические расстройства. Субъектом коррекционного образования, на который направлено изучения, воспитания, обучения и коррекционная психолого-педагогическая помощь, является ребенка с недостатками психофизического развития. Также научно обосновано влияние рождения ребенка с пороками развития на психоэмоциональное состояние и адаптацию родителей. $\mathrm{C}$ теоретического анализа установлено, что семья, воспитывающая ребенка с ограниченными психофизическими возможностями, ребенка, которому установлена инвалидность, или хронически больного ребенка, проходит стадии, Выделены основные стадийные факторы и критерии к постановке диагноза. А также установлено, что именно с учетом этого определяются содержание и методы работы с ребенком, и форма организации обучения и воспитания. В статье проанализированы научные данные и научные подходы к исследованию: проблем родителей, возникающие вследствие заболевания их ребенка; эмоциональных состояний у родителей, воспитывающих ребенка с нарушением развития. Этапы работы несут в себе: информаций обеспечения ребенка; помощь в поиске адекватных способов преодоления трудностей, своих скрытых ресурсов; дифференцированная психологопедагогическая поддержка.

Ключевые слова: проблеми родителей ребенка с отклонениями в развитии, эмоциональные состояния, чувство вини, депресия, психологическая помощь.

Дата отримання статті: 13.10.2017 Дата рекомендації до друку: 23.10.2017 